\title{
PEMETAAN ZONASI POTENSI PARIWISATA BERBASIS PARTISIPASI MASYARAKAT DI DESA CIKOLELET
}

\author{
Rendy Akbar $^{1}$, Deasy Olivia ${ }^{2}$, Ade Firmansyah ${ }^{3}$, Ida Ayu Sawitri Dian Mawarni ${ }^{4}$, Rachmat \\ Taufick Hardi ${ }^{5}$, Andi M. Ahsan ${ }^{6}$ \\ ${ }^{123456}$ Program Studi Perencanaan Wilayah dan Kota, Universitas Pradita \\ rendy.akbar@pradita.ac.id
}

\begin{abstract}
Abstrak
Desa Cikolelet merupakan desa wisata yang berada pada Kecamatan Cinangka, Kabupaten Serang. Desa Cikolelet menawarkan wisata pedesaaan yang terdiri dari curug, lahan persawahan, peternakan kambing etawa, perkebunan dan perikanan darat, serta desa ini juga kaya akan seni dan budaya warisan leluhur yang masih terpelihara hingga saat ini seperti tradisi mamaca, tarian rampak bedug, debus, festival tahunan ngagurah dano, upacara prah-prahan, dan sebagainya.Namun, belum terarahnya arahan pengembangan Pariwisata Desa Cikolelet yang statusnya sebagai Desa Wisata. Kurang jelasnya arahan pengembangan Desa Cikolelet sebagai desa wisata terlihat pada kondisi infrastruktur seperti akses jalan menuju obyek - obyek wisata masih berupa jalan tanah dan kondisinya yang menyulitkan untuk pengembangan pariwisata.

Oleh karena itu, untuk membantu pengembangan potensi Desa Cikolelet sebagai Desa wisata maka disusun PKM berupa pemetaan zonasi potensi pariwisata berbasis masyarakat di Desa Cikolelet. Dengan adanya kegiatan PKM ini diharapkan dapat membantu para pembuat kebijakan pada Desa Cikolelet dalam membuat arahan pengembangan pariwisata Desa Cikolelet yang lebih terarah dan terstruktur dengan melibatkan masyarakat dalam proses pelaksanaanya. Tahapan inti dalam kegiatan PkM ini adalah mengidentifikasi potensi pariwisata Desa cikolelet dengan melibatkan masyarakat dalam pelaksanaannya dan dilanjutkan dengan tahapan pembuatan peta zonasi potensi Pariwisata Desa Cikolelet dengan melibatkan stakeholder dan masyarakat. Kegiatan PKM ini diharapkan juga dapat meningkatan kualitas tata kelola pembangunan masyarakat desa khususnya pada sektor pariwisata.
\end{abstract}

Kata Kunci : Pemataan Zonasi, Potensi Pariwisata, Partisipasi Masyarakat, Desa Wisata

\section{PENDAHULUAN}

Desa Cikolelet merupakan desa wisata yang berada pada Kecamatan Cinangka, Kabupaten Serang. Desa wisata adalah sebuah kawasan pedesaan yang memiliki beberapa karakteristik khusus untuk menjadi daerah tujuan wisata (Zakaria \& Suprihardjo, 2014). Desa Cikolelet menawarkan wisata pedesaaan yang terdiri dari lahan persawahan, peternakan kambing etawa, perkebunan dan perikanan darat, serta desa ini juga kaya akan seni dan budaya warisan leluhur yang masih terpelihara hingga saat ini seperti tradisi mamaca, tarian rampak bedug, debus, festival tahunan ngagurah dano, upacara prah-prahan, dan sebagainya. Sejak ditetapkan sebagai desa wisata, Cikolelet juga melakukan penataan di beberapa objek wisata alam yang ada, diantaranya dengan membuat area spot foto, rumah pohon dan camping ground di Puncak Pilar dan Gunung Cibaja. 
Lingkup desa wisata dapat berupa alam seperti gunung, persawahan, hutan, tebing, bentang alam, flora dan fauna, juga taman laut; budaya seperti peninggalan sejarah,adat istiadat, tradisi, kehidupan sehari-hari, dan karya arsitektur (Arida et al., 2019).

Dalam pengembangan desa wisata perlu mempertimbangkan berbagai potensi yang ada untuk mendukung pengembangan pariwisata desa (Made Darma Oka et al., 2018). Pengembangan desa wisata diharapkan dapat mengembangkan potensi lokal yang bersumber dari alam, sosial budaya dan ekonomi guna memberikan kontribusi bagi ekonomi lokal (Made Darma Oka et al., 2018). Pengembangan desa wisata memiliki tujuan utama untuk membangun masyarakat desa agar memiliki ketahanan budaya dan ekonomi (Arida et al., 2019). Pengembangan potensi pariwisata bisa dalam bentuk peta yang berisi informasi zonasi potensi yang dimiliki oleh desa. Peta merupakan wahana bagi penyimpanan dan penyajian data kondisi lingkungan, merupakan sumber informasi bagi para perencana dan pengambilan keputusan pada tahapan dan tingkatan pembangunan (Bakosurtanal, 2005).

Permasalahan yang terjadi antara potensi sumber daya alam dengan sumber daya manusia adalah masyarakat tidak mengoptimalkan potensi sumber daya yang ada untuk memanfaatkan sebagai potensi wisata (Zakaria \& Suprihardjo, 2014). Dengan adanya pemetaan potensi zonasi pariwisata Desa Cikolelet berbasis masyarakat dapat membantu arahan pengembangan dari masing masing jenis pariwisata yang terdapat pada Desa Cikolelet. Pemetaan potensi wisata akan memudahkan dalam proses pengembangan dan pengelolaan (Sucipto \& Rukmana, 2019). Selain itu, Pemetaan zonasi potensi desa wisata bertujuan untuk memetakan potensi daerah-daerah wisata dalam hal ini adalah desa wisata, sehingga akan mempermudah dalam pengaksesan lokasi bagi para wisatawan ataupun instansi lain yang membutuhkan (Putra \& Fauzy, 2015).

Desa Cikolelet masih belum cukup baik dalam mengakomodasi kebutuhan para wisatawan untuk mengunjungi obyek wisata. Kondisi jalan yang masih berupa jalan tanah sangat menyulitkan para wisatawan untuk mengunjungi obyek wisata. Beberapa obyek wisata yang dimiliki Desa Cikolelet seperti wisata alam Curug Kembar dan Curug Lawang hanya dapat diakses dengan berjalan kaki selama 30 sampai 45 menit. Selain itu, Desa Cikolelet belum memiliki peta potensi pariwisata yang sangat penting sebagai median informasi bagi wistawan. Oleh karena itu, dengan adanya Kegiatan PkM pemetaan zonasi potensi Desa Wisata Cikolelet dapat membantu dalam arahan pengembangan prioritas potensi pariwisata Desa Cikolelet.

Secara umum program pengabdian masyarakat ini bertujuan untuk dapat memetakan potensi wisata yang dimiliki oleh Desa cikolelet berbasis masyarakat. Setelah diketahui secara spesifik potensi wisata Desa Cikolelet maka diharapkan dapat membantu para pengambilan kebijakan Desa Cikolelet dalam membuat usulan prioritas arahan dalam pengembangan Desa Cikolelet sebagai desa wisata dan juga dapat menjadi media informasi bagi para wisatawan yang berkunjung ataupun warga desa terkait potensi wisata yang dimiliki oleh Desa Cikolelet.

\section{METODE}

Pelaksnaan kegiatan pengabdian kepada masyarakat ini dilakukan dalam tiga tahapan yaitu tahap pertama sebagai tahap awal atau persiapan. Pada tahap ini dilakukan kegiatan pertemuan pendahuluan dan survey lapangan berupa menemui kepala desa dan pokdawis Desa Cikolelet, Selain itu, pada tahap ini juga dilakukan survey lapangan berupa pendampingan terhadap masyarakat dalam pemetaan potensi lokasi pariwisata Desa Cikolelet. Kemudian tahap selanjutnya adalah tahap pelaksanaan kegiatan pengabdian masyarakat yang berupa FGD (Focus Group Discussion) pemetaan zonasi potensi pariwisata Desa Cikolelet dengan melibatkan stakeholder dan masyarakat. Kemudian output dari kegiatan FGD ini ditindaklanjuti dengan kegiatan pembuatan peta zonasi potensi pariwisata Desa Cikolelet yang akan dilaksanakan oleh tim pelaksana PKM. Tahap terakhir adalah tahap evaluasi. Pada tahap ini dilakukan evaluasi atas hasil yang dilakukan oleh kedua belah pihak Desa Cikolelet. Setelah tahap evaluasi barulah peta zonasi potensi paiwisata akan diserahkan secara resmi kepada pihak desa dan akan dibantu untuk ditampilkan secara online dalam bentuk website agar dapat menjadi media promosi bagi Desa Cikolelet. Untuk kerangaka pelaksanaan kegiatan pengabdian masyarakat pemetaan zonasi potensi

Teknologi Informasi dan Komunikasi 75 
wisata Desa Cikolelet dapat dilihat pada gambar berikut ini.

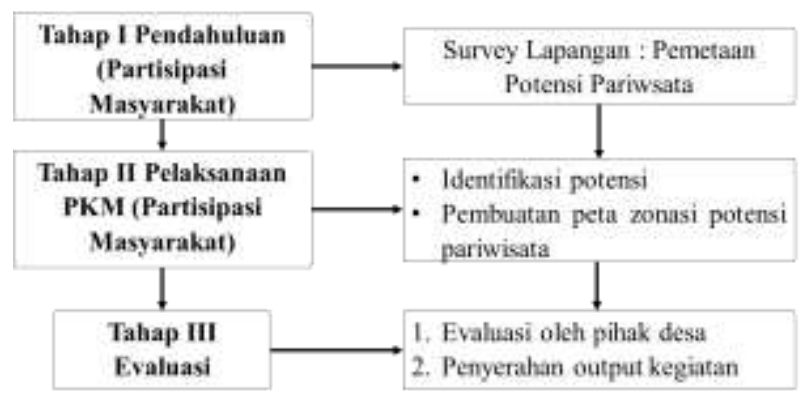

Gambar 1. Kerangka Pelaksanaan PKM

\section{HASIL DAN PEMBAHASAN}

Secara keseluruhan tahapan PKM yang telah dilaksanakan tebagi menjadi 3 yaitu tahap pendahuluan, pelaksanaan dan evaluasi PKM. Untuk waktu pelaksanaan PKM ini terbagi menjadi dikarenakan adanya pandemik Covid 19 yang sedang berlangsung. Pelaksanaan tahap pendahuluan dan pelaksanaan PKM berlangsung pada 2 - 9 Desember 2019 yang kemudian tahap evaluasi baru dapat dilaksanakan secara daring pada 24 September 2021.

\section{Tahap Pendahuluan}

Tahap pendahuluan berupa kegiatan survey lapangan terkait pemetaan lokasi pariwisata di Desa Cikolelet. Kegiatan survey awal PKM dilaksanakan untuk mengetahui potensi pariwisata yang dimiliki Desa Cikolelet. Pihak yang terlibat dalam pelaksanaan survey lapangan ini adalah para pemuda desa yang bergabung ke dalam Pokdawis sebagai salah satu bentuk partisipasi masyarakat yang didampingi oleh tim pelaksana PKM. Jumlah pelaksana survey lapangan ini berjumlah 10 orang yang terbagi kedalam 5 kelompok dan tim pelaksananya berjumlah 4 orang yang terdiri dari 2 orang dosen dan 2 orang mahasiswa.
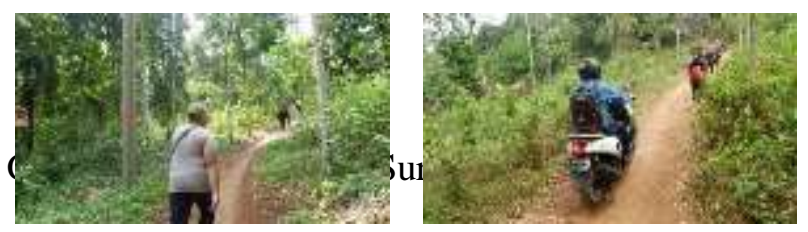

Pada pelaksanaan kegiatan survey lapangan ini menggunakan media peta survey yang telah disiapkan oleh pelaksana tim survey sebelum kegiatan survey lapangan dan juga menggunakan aplikasi GeoJot+ yang digunakan sebagai alat bantu survey untuk memudahkan pelaksanaan survey lapangan. Sebelum pelaksanaan survey lapangan ini dilaksanakan pelatihan singktacara melakukan survey dengan bantuan peta survey dan cara penggunaan penggunaan aplikasi GeoJot+ di smartphone peserta. Pelaksanaan survey lapangan ini dimulai pada tanggal 2 - 3 Desember 2019.

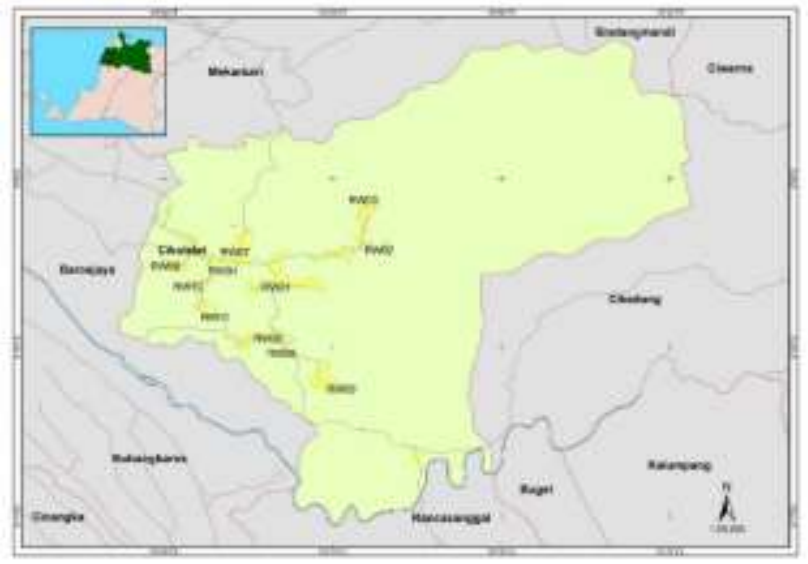

Gambar 2. Peta Survey yang digunakan Sebagai Media Bantu Pelaksanaan Survey Lapangan

Tahapan selanjutnya setelah pelaksanaan survey lapangan adalah pengolahan hasil survey lapangan yang dilakukan oleh tim pelaksana PKM. Proses pengolahan data hasil survey berupa sebaran potensi lokasi pariwisata menggunakan ArcGis. Tahapan pengolahan hasil survey ini memakan waktu selama 2 hari. Tahapan pengolahan hasil survey akan menghasilkan peta lokasi potensi pariwisata yang akan digunakan sebagai alat bantu pada tahap pelaksanaan PKM di Desa Cikolelet sehingga dapat mengetahui gambaran umum potensi lokasi pariwisata yang update dan digunakan dalam pelaksanaan PKM di Desa Cikolelet

Bentuk partisipasi masyarakat dalam tahap pendahuluan ini adalah berupa pendampingan kepada masyarakat desa dalam pelaksanaan survey lapangan. Bentuk pendampingan dalam pelaksanaan PKM adalah dengan melakukan pelatihan singkat

Teknologi Informasi dan Komunikasi 76 
tata cara pelaksanaan survey lapangan terkait potensi pariwisata yang ada di Desa Cikolelet dengan menggunakan alat bantu berupa peta survey dan aplikasi GeoJot+.

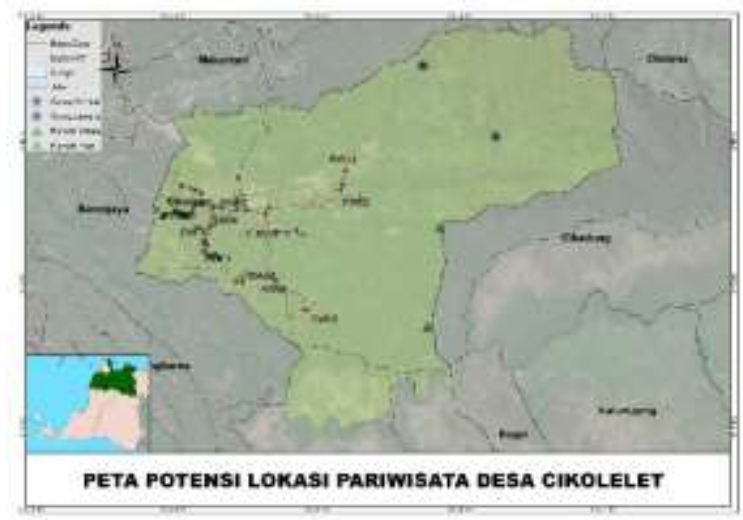

Gambar 3. Peta Potensi Lokasi Pariwisata Desa Cikolelet

\section{Tahap Pelaksanaan}

Tahap pelaksanaan PKM berlangsung pada tanggal 6 Desember 2019 berupa kegiatan FGD dalam penentuan zonasi potensi pariwisata dengan menggunakan peta potensi lokasi pariwisata yang telah dihasilkan dari tahap sebelumnya. Kegiatan pelaksanaan PKM ini melibatkan beberapa stakeholders yang terdapat di Desa Cikolelet. Jumlah masyarakat yang terlibat didalam kegiatan ini berjumlah 30 orang.

Mekanisme pelaksanaan FGD kegiatan PKM ini diawali dengan penjelasan tujuan adanya peta zonasi potensi pariwisata Desa Cikolelet dengan adanya peta zonasi potensi pariwisata ini diharapkan dapat menjadi arahan pengembangan pariwisata dan menjadi media informasi bagi wisatawan ataupun calon wisatawan terkait potensi yang dimiliki oleh Desa Cikolelet.

Setelah agenda penjelasan tujuan program PKM ini dilaksanakan maka tahapan selanjutnya adalah diskusi terkait penentuan zonasi potensi pariwisata yang dimilik Desa Cikolelet. Proses diskusi ini dilakukan oleh stakeholders yang terdapat di Desa Cikolelet yang difasilitasi oleh para tim pelaksana PKM. Serta nantinya output dari tahap ini akan ditindaklanjuti dengan proses pembuatan Peta Zonasi Potensi Pariwisata Desa Cikolelet oleh tim pelaksana PKM.

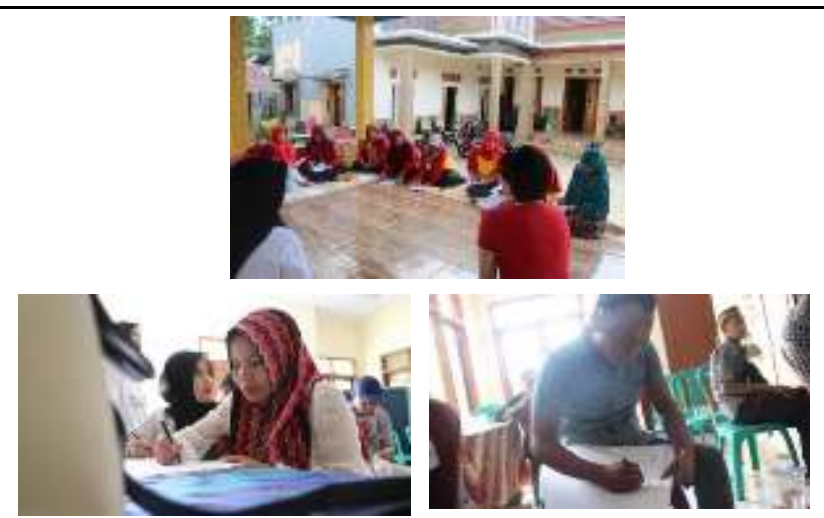

Gambar 4. Pelaksanaan PKM berupa FGD di Desa Cikolelet

Kegiatan pelakasanaan PKM ini secara umum bertujuan sebagai menampung aspirasi masyarakat yang dalam hal ini diwakili oleh para Stakeholders Desa Cikolelet dalam penentuan zonasi potensi pariwisata Desa Cikolelet yang kemudian akan coba diterjemahkan oleh tim pelakasana PKM kedalam bentuk Peta Zonasi Potensi Pariwisata Desa Cikolelet.

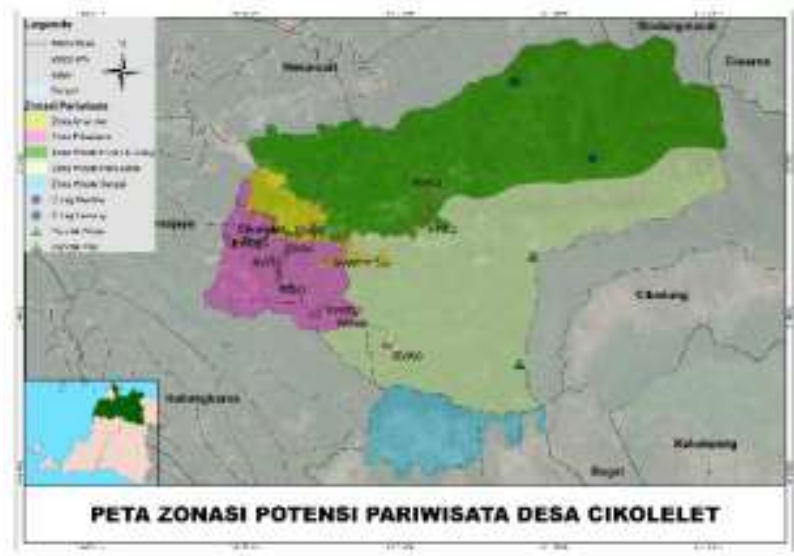

Gambar 5. Peta Zonasi Potensi Pariwisata Desa Cikolelet

Secara umum berdasarkan hasil FGD yang diterjemahkan kedalam Peta Zonasi Potensi Pariwisata, terdapat 5 zona yang terdapat di Desa Cikolelet yaitu Zona Amenitas, Zona Eduwisata, Zona Wisata Hutan dan Curug, Zona Wisata Perbukitan dan zona wisata sungai. Proses penentuan zona ini didasari oleh sebaran lokasi pariwisata. Sebagai contoh untuk zona wisata hutan 
dan curug dikarenakan didalam zona tersebut terdapat potensi curug dan kawasan hutan.

\section{Tahap Evaluasi}

Pelaksanaan tahap evaluasi dalam kegiatan PKM ini sedikit terlambat dari jadwal yang direncanakan krena adanya pandemik Covid - 19 . Tahapan ini baru terlaksana pada 24 September dengan menggunakan metode secara daring. Kegiatan ini berupa paparan atau penjelasan terkait out Peta Zonasi Potensi Pariwisata yang telah dihasilkan. Selain itu didalama kegiatan ini menjadi evaluasi terkait proses pelaksanaan PKM yang telah dilaksanakan dan membahas program lanjutan PKM yang dapat dilaksanakan selanjutnya. Selain itu, didalam tahapan ini juga secara simbolis penyerahan output PKM yang telah dilaksanakan berupa Peta Zonasi Potensi Pariwisata Desa Cikolelet yang akan mengakhiri rangkaian kegiatan program PKM ini.

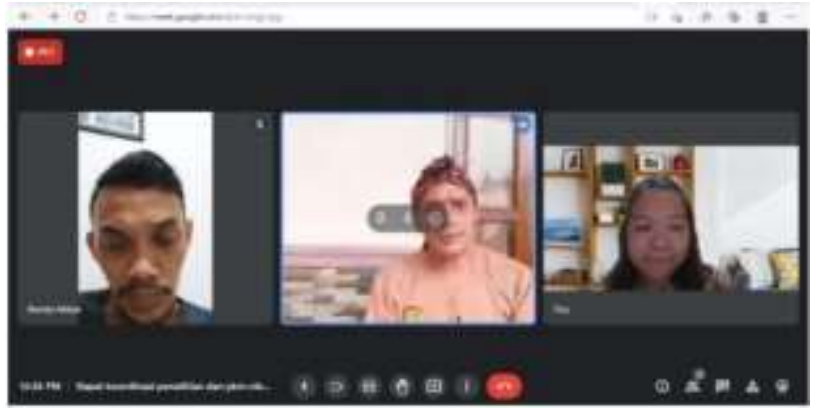

Gambar 6. Pelaksanaan Evaluasi Kegiatan PKM yang Telah dilaksanakan Secara Online

\section{KESIMPULAN}

Dengan pelaksanaan PKM ini diharapkan akan sangat bermanfaat dalam penyelesaian permasalahan dalam pengembangan potensi pariwisata yang dimiliki oleh Desa Cikolelet. Dengan beragamnya potensi pariwisata yang dimiliki oleh Desa Cikolelet diharapakan arahan pengembangan dapat terarah dalam memaksimalkan potensi yang dimiliki oleh Desa Cikolelet. Program PKM berupa pemetaan zonasi potensi pariwisata Desa Cikolelet berangkat dari permasalahan kurang terarahnya dalam pengembangan potensi pariwisata dan kurangnya informasi terkait potensi pariwisata di Desa Cikolelet. Dengan adanya kegiatan PKM ini diharapkan dapat berimplikasi terhadap arahan pengembangan potensi pariwisata yang lebih terarah dan sebagai media informasi yang jelas dan up to date kepada para wisatawan yang berkunjung di Desa Cikolelet serta melatih/menanamkan partisipasi masyarakat turut serta dalam pengembangan parwisata di Desa Cikolelet.

\section{UCAPAN TERIMAKASIH (Bila ada)}

Ucapan terima kasih kami tujukan untuk Desa Cikolelet selaku mitra pelaksanaan PKM, khususnya untuk stakeholders dan masyarakat Desa Cikolelet atas waktu dan kesediaannya bersamasama dalam melaksanakan kegiatan ini. Selain itu, ucapan terima kasih juga kami tujukan untuk Lembaga Penelitian dan Pengabdian Masyarakat (LPPM) Universitas Pradita yang mendanai pelaksanaan PKM ini

\section{REFERENSI}

Arida, N. S., Pujani, K. (2019). Kajian Penyusunan Kriteria-Kriteria Desa Wisata Sebagai Instrumen. Jurnal Analisis Pariwisata, 17(1), 1-9.

Bakosurtanal. 2005. Pengertian Peta (Online).http://geografi.com/2009/09/ pengertianpeta.htm

Made Darma Oka, I., Nyoman Winia, I., \& Ketut Sadia, I. (2018). Pemetaan Potensi Pariwisata Dalam Mendukung Pengembangan Pariwisata di Desa Serangan. Bhakti Persada, 4(1), 47-54.

Putra, A. S., \& Fauzy, A. (2015). Pemetaan Lokasi Potensi Desa Wisata Di Kabupaten Sleman Tahun 2015. Ajie, 4(2), 123-129. https://doi.org/10.20885/ajie.vol4.iss2.art7

Sucipto, \& Rukmana, S. N. (2019). Identifikasi Pemetaan Potensi Kawasan Wisata. Jurnal Planologi, 16(2), 147-157.

Zakaria, F., \& Suprihardjo, D. (2014). Konsep Pengembangan Kawasan Desa Wisata di Desa Bandungan Kecamatan Pakong Kabupaten Pamekasan. Teknik Pomits, 3(2), C245-C249. https://doi.org/2337-3520.

Teknologi Informasi dan Komunikasi 